\title{
Divided by the Rainbow: Culture War and Diffusion of Paleoconservative Values in Contemporary Poland
}

\author{
Ryszard Bobrowicz $^{1, *(D)}$ and Mattias Nowak ${ }^{2}$ \\ 1 Centre for Theology and Religious Studies, Lund University, 22100 Lund, Sweden \\ 2 European Studies, Lund University, 22100 Lund, Sweden; mattias.nowak@eu.lu.se \\ * Correspondence: ryszard.bobrowicz@ctr.lu.se
}

Citation: Bobrowicz, Ryszard, and Mattias Nowak. 2021. Divided by the Rainbow: Culture War and Diffusion of Paleoconservative Values in Contemporary Poland. Religions 12 170. https://doi.org/10.3390/ rel12030170

Academic Editors: Tobias Köllner and Boris K. Knorre

Received: 29 December 2020

Accepted: 2 March 2021

Published: 5 March 2021

Publisher's Note: MDPI stays neutral with regard to jurisdictional claims in published maps and institutional affiliations.

Copyright: (c) 2021 by the authors. Licensee MDPI, Basel, Switzerland. This article is an open access article distributed under the terms and conditions of the Creative Commons Attribution (CC BY) license (https:// creativecommons.org/licenses/by/ $4.0 /)$.

\begin{abstract}
Over the last decade, representations of the rainbow were repeatedly disputed in Poland, revealing the country's ongoing socio-political changes and its drift away from the generally liberal and secular values of the European mainstream. These cases show a political growth and an increasing social diffusion of Polish 'national paleoconservatism.' The aim of this article is to (1) discuss the intellectual roots of this distinct form of conservatism built upon the confrontational notions of national identity, patriotism, and Catholicism; (2) propose a novel concept in the studies of Polish politics ('national paleoconservatism'); and (3) present the social diffusion of such conservatism based on conflicts over representations of the rainbow. By combining the historical and intellectual background with the contemporary case studies, the authors aim to facilitate a deeper understanding of the vitality of national conservative ideas among internationally unknown conservative intellectuals, who participate in a discursive 'culture war' against their liberal, progressive and secular opponents in present-day Poland. The ideological conflicts revolve around the meaning of Polish national identity, the essential character of the country's culture, and the position of Poland within the framework of European integration.
\end{abstract}

Keywords: Poland; culture war; rainbow; LGBTQ+; conservatism; paleoconservatism; Law and Justice; Roman Catholicism; public sphere

\section{Introduction}

Since 2015, when the parliamentary elections brought the national conservative party Law and Justice to governmental power, many socio-political developments in Poland have provoked waves of heated and critical comments in both Western media and scholarly works. More and more frequently, journalists, scholars and politicians of the "old EU" presented Poland as a country headed by illiberal, traditionalist, populist and Euro-sceptic political elites. Polish political and legal frameworks were condemned, due to suspected violations of the rule of law and politicization of public media. The critical discourse depicted Polish social and cultural life as besotted with traditionalist values and practices, incompatible with the rather liberal and secular character of the European integration. Repeatedly, controversies concerning abortion, gay rights, gender equality, and xenophobia were raised in Western media under thought-provoking titles, e.g., Poland's Culture Wars (Rohac and Kokonos 2020), Poland's Nationalism Threatens Europe's Values, and Cohesion (Erlanger and Santora 2018) and/or Poland LGBT: Diplomats from 50 countries call for end to discrimination (BBC News 2020). This discourse, describing Poland as hardline conservative, found support among many commentators from Central and Eastern Europe (see, e.g., Bodziony 2020; Godzisz and Rawłuszko 2018; Graff 2010; Grzebalska and Pető 2018; Korolczuk 2017; Kováts 2016, 2018). Both within the "old EU" and in Central-Eastern European liberal discourses, the aforementioned illiberal developments were frequently blamed on governmental policies and the prevalent role of the Catholic Church in Poland. The socio-political success of conservative ideals was often seen as a somewhat surprising 
challenge to the so-called 'European values' ${ }^{1}$, for instance, when the recent state of affairs was juxtaposed with images of swiftly modernizing and liberalizing Poland of the 1990s and 2000 s. $^{2}$ Although partially accurate, this critical discourse, accompanied by the feeling of surprise, often bears two interconnected analytical limitations that are identified, addressed and, hopefully, resolved in this article.

First and foremost, the discourse frequently focused on institutional macro-levels, and, therefore, led to generalized, critical depictions of the government, the ruling party, the Church, the clergy, and/or the public media. This tendency was apparent in studies of Poland already in the 1990s and remained apparent even in more recent works. For instance, in 1998, Mirella Ebert argued that, since the fall of communism, the Church had tried to gain influence on policy-making processes enhancing dilemmas for the democratic system. In a similar vein and in a recent monograph, entitled The Catholic Church in Polish History: From 966 to the Present, Ramet (2017) criticized the Church's contemporary political involvements. Ramet focused predominantly on the clergy, somewhat neglecting other aspects of Catholic life, e.g., elaborations of theological dimensions or of the societal importance of lay faithful (compare: Alvis 2018; Köllner 2020). In general, little scholarly attention was given to conservative intellectual milieus, including individual thinkers, such as political philosophers, sociologists and theologians, who give tone and legitimacy to Polish conservative thought. The intellectual roots of the current conservative wave are rather absent from the discussions concerning the ongoing socio-political developments in Poland.

Second, such generalizations led to a simplified understanding of the current relationship between the Catholic Church in Poland and the government led by the Law and Justice party. Although many high-ranking members of the Polish Episcopate offered religious arguments to support governmental decisions, their actions can be ascribed to neither simple opportunism nor political ambitions. The Church's support of the governmental decisions may rather be motivated by two other, often overlooked, factors. On the one hand, the Polish Catholic clergy was long involved in the struggle for the country's political and cultural independence and sovereignty during times of foreign oppression (for comparison with other post-Communist countries, see, e.g., Köllner 2019). On the other hand, individuals from both the Church and the broadly understood political right were and still are active in the same intellectual milieus, that is, share the same moral convictions. In some cases, cooperation between political and religious actors may be motivated strategically and serve individual agendas. In others, the long-standing tradition of nationalized Catholicism makes some members of the Catholic Church in Poland susceptible to the version of national conservatism represented currently by Law and Justice. ${ }^{3}$

Over the last decade, various representations of the rainbow, and debates on its political and religious meanings, became an apparent symbol of social and political changes in Poland, including the country's drift away from the liberal and secular values of the Western European mainstream. From the multiple arson attempts that, to varying degrees, consumed Julita Wójcik's installation representing a rainbow made out of artificial flowers,

1 The notion of 'European Values' bears a high normative load, and yet lacks sufficient critical clarification. These values are often viewed as self-evident, which is, however, problematic. For instance, although some may view Polish conservatism as incompatible with European values, many Polish conservatives would actually view themselves as representing the 'true' European values in opposition to the decadent Europe. Therefore, these discourses require critical rethinking in future scholarly works.

2 Nationalist and conservative tendencies were a strongly visible part of Polish societal life since the end of Communism. Traditionalist ideals were successfully championed by various actors for decades. However, in the later part of the 2000s and in the 2010s, the strength of conservative politics, embodied primarily by the Law and Justice party, became fiercely imprinted in the mainstream political life. Simultaneously, conservative values were increasingly diffused in broad sectors of the Polish society. (compare McManus 2020, pp. 188-91).

3 In an analysis of religion and politics in contemporary Russia, Köllner (2021) writes about "entangled authorities", a term which might shed some light also at the situation in Poland. As Köllner writes, the relation of the two should be viewed as "a complex and open-ended process of cooperation, negotiation, contestation and confrontation between two powerful actors. In this interplay, neither side is able to instrumentalize the other completely or permanently. Instead, the concept of 'entangled authorities' was developed to draw attention to the entanglements between both sides. Although an entanglement might look very much the same as the outcome of a close cooperation, the processes involved are complex, not straightforward, and include a great number of unintended results. Entanglements, thus, are not the glorious implementation of a well-thought-out plan but the result of social interactions, which might have had completely different goals and intentions" (p. 3). 
to the use of state coercion to punish citizens that decorated religious representations with the symbol of the rainbow, these cases showed the social expansion and diffusion of a specific form of conservative identity politics. The aim of this article is (1) to discuss the intellectual roots of a specific symbiosis between nationalism, conservatism, and a nationalized approach to Catholicism that had a significant impact on the contemporary Polish politics; (2) to propose a novel conceptual tool for analyzing right-wing politics in Poland-'national paleoconservatism'; and (3) to present, using three case studies, the societal diffusion of that conservatism during the 2010s. The authors aim to provide a deeper understanding of the vitality of nationalist and conservative ideas among internationally unknown, or relatively unknown, Polish conservative intellectuals, who are engaging in a discursive 'culture war' (see Hunter 1991) with their liberal, progressive and secular opponents. This 'culture war' revolves around the meaning of Polish national identity, the essential character of the country's culture, and the position of Poland within the framework of European integration.

\section{The Terminology, History, and Meaning of Conservatism in Poland}

In recent decades, right-wing political currents in Europe have been on the rise. Many scholars paid attention to this phenomenon, but, unfortunately, the lack of common, established terminology led to conceptual confusion. Namely, scholars proposed a number of terms that denoted overlapping yet not identical ideological stances, such as far right (e.g., Mudde 2019; Sofos 2019), right-wing populism (e.g., Hockenos 2010; Wodak 2013), national populism (e.g., Brubaker 2017; Eatwell and Goodwin 2018), paternalist populism and illiberal elitism (Enyedi 2016), illiberalism (e.g., Grzebalska and Pető 2018; Makarychev 2019), the new nationalism (Halikiopoulou and Vlandas 2019), national conservatism (Borén et al. 2020), radical conservatism (Drolet and Williams 2018), biopolitical conservatism (Yatsyk 2019), and post-modern conservatism (McManus 2020). Distinctions between definitions of these terms remain blurred. As Cas Mudde (2007, p. 12) put it, "The terminological chaos is not the result of fundamental differences of opinion over the correct definition; rather, it is largely the consequence of a lack of definitions."

Despite the variety of existing concepts and terms, many recent studies of Polish socio-political life concur that the country is led by an illiberal government that challenges mainstream 'European values.' Such values are generally liberal-democratic, secular and multicultural in character (compare: Vignoles et al. 2018). In opposition to the progressive stances on such matters as family policies, gender equality, LGBTQ+ rights, abortion and cultural pluralism prevalent in the 'old EU', Poland is viewed as a country that embodies cultural ideas associated with European populist right. According to Erel (2018), such populist positions overlap with conservative discourses and emphasize the ideas of a beleaguered continent, under threat from overwhelming feminism, gender politics and multiculturalism. However, even if we accept that depicting Poland as a state with cultural politics permeated by right-wing discourses is accurate, such depictions seldom thoroughly account for why social conservatism and traditional values continue to constitute a vital dimension of Polish societal life. Nor do they provide an in-depth insight into the fundamental sources of the ideological content and intellectual legitimacy of Polish traditionalism.

The Catholic Church, with its doctrinal and social teachings, is an important source of such ideological content and intellectual legitimacy. Like other religious institutions around the world, the Catholic Church provides a framework of values that are relevant to the social and cultural morphology of states. However, the Catholic Church, despite being the largest denomination in Poland, is neither a dominant nor a uniform political force. Viewing either the Catholic Church in Poland, or even just the Episcopate, as a uniform political force may lead to the aforementioned over-simplifications. Religious authorities, however influential, do not independently govern the country. While many clerical figures play a significant role in the public life, and levels of religious affiliation and individual belief are often presented as a counter-example to the secularization thesis (see, 
e.g., Casanova 1994), Polish religious landscape remains as complex as that of many other European countries. Furthermore, the social teachings of the Catholic Church are used as a part of the political game. For example, such teachings are sometimes manipulatively used by political actors seeking to legitimize their own activities. Such partnerships are always about individuals, that is, individuals among clergy partner up with individual politicians or political parties. In fact, overlaps between the activities of Polish conservative and nationalist politicians, and those of the nationally-minded supportive clergy, may even de facto conflict with the universal Catholic positions, e.g., the Papal call to welcome refugees (Orłowski 2017). Furthermore, several recent surveys demonstrated that some measures of secularization have actually significantly increased in Poland in recent decades (Pew Research Center 2018). Therefore, we offer a more in-depth picture of the Polish context and illustrate that current national conservatism builds on historically established intellectual traditions. These traditions were, and still are, associated with the historical and social position of the Catholic Church in Poland. However, they are also related to the unique ideological and intellectual heritage. In other words, we believe that understanding the Polish context requires an in-depth knowledge about the history of Polish political culture, and the following three interconnected patterns in particular:

- A specific historical role assigned to the so-called Intelligentsia, that is, prominent intellectual, cultural and spiritual authorities. Throughout history, and in particular during foreign oppression and lack of independence, Polish political elites comprised primarily political thinkers, artists, poets and members of the clergy. The independent Polish state did not exist during the nineteenth and early twentieth century. As Polish scholars lacked own academic institutions during that time, they were viewed as political and moral actors rather than just professionals (compare Jedlicki 1999).

- Specific national identity involving somewhat mythologized self-images of Intelligentsia. Poland and its sovereignty were viewed as a geopolitical and cultural bridge between the European West and East.

- Close discursive relations between the political and conservative cultural spheres. The ideas of political independence were often associated with traditionalism and the assumption of a Polish civilizational mission, especially in the European East. Although these ideas proliferated in nineteenth-century Polish Romanticism, they have been a part of Polish political culture for centuries.

These three interconnected patterns are fundamental for the content and the enduring power of the specific version of national conservatism in present-day Poland.

\subsection{Historical Foundations of Conservatism in Poland}

Polish political culture evolved, among others, from the heritage of 'conservative republicanism' and limited imperial ambitions represented by the nobility of the PolishLithuanian Commonwealth between the sixteenth and the eighteenth century. The nobility, unusually large and powerful as compared to the rest of Europe, viewed Poland as Antimurale Christianitas, a wall protecting Latin Christian Europe from both the Ottoman Empire and Russian imperialism. The Commonwealth was known for general religious tolerance, a part of its 'republican tradition', and was inhabited by Catholics, Orthodox, Uniates, Lutherans, Jews, and Muslims (see Tazbir 1973). Nonetheless, the Catholic Church had the majority position that laid foundations for a symbiosis between Catholicism and the idea of 'Polishness.' Marian devotion, for instance, played an important role in the growth of national consciousness. The mythologized depiction of Virgin Mary at Jasna Góra was viewed by many as the savior of the Catholic defenders during the war with Sweden in the seventeenth century. Even today, this icon of Black Madonna remains enormously worshipped in Poland.

Political ideas developed in early modern times continued to permeate Polish society, especially its intellectual elites, during the nineteenth and early twentieth century. Since the eighteenth century, the Commonwealth had been divided between the neighboring powers, Russia, Prussia, and Austria, and remained absent from the map of Europe. Many Polish 
thinkers, poets, artists and members of the clergy would nevertheless maintain that Poland was an inherent part of the West. In contrast to the ideals of French Revolution, with its liberal and secular ideas, Polish Intelligentsia claimed that the West was based on Christian culture and heritage, not on revolutionary and progressive ideals. The values and ideals of the 'conservative republican' nobility intertwined with the developing Polish Romanticism. The Romantic movement created and broadly disseminated two socio-political myths that became crucial in modern Polish political culture: the 'insurrection myth' and the 'miracle myth' (Törnquist-Plewa 1992). Such political myths are a part of political cultures, and serve as narratives about the community's past, merging images of historical experiences and identities with notions of community's present and future. Myths mobilize collective emotions and attitudes. They also inform community's perception of what is right or wrong, desired of feared. (compare: Dutceac Segesten 2011; Törnquist-Plewa 1992). In Polish history, the mythological images of insurrections indebted each successive generation of Poles to the ancestors who fought and sacrificed own lives for the freedom of the occupied fatherland. The 'miracle myth' relied on a claim of "chosen people", whose sacrifices and dedication to the heroism and tradition of past generations would, one day, bring a reward. Such sacrifices would ultimately fulfill the political dreams of independence and peace. As Törnquist-Plewa (1992, pp. 254-55) put it, "The concept of sacrifice as sacrum proves that both these myths were influenced by Christian thought in their formation, and especially by the motive which in a particular way transposed into the ideas of Polish Messianism." During the nineteenth and early twentieth century, modern national identity discourses were preoccupied with struggle for preservation of national culture in times of foreign oppression. This does not mean that progressive ideological currents, e.g., liberalism and socialism, did not hold vital positions in the political culture. They did. So did positivism in the educational and economic sphere, with its significant dedication to modernity. However, the geopolitical circumstances and the existing political heritage promoted ideals associated with the struggle for national independence, national/cultural protectionism and Catholicism. As stated by the historian Andrzej Walicki (1982, p. 59): "In partitioned Poland the "national question", in its many dimensions, was so overwhelmingly important, and so central to intellectual life, that problems of economic development were, as a rule, totally subordinated to it". The political culture and the formation of the collective national consciousness were particularly influenced by Polish romanticism and neo-romanticism, and the resulting national-liberation movements. According to Törnquist-Plewa (1992, p. 258), no other intellectual outlook presented by Polish elites could match the mythologized images of the romantically inclined patriots. The history of uprootedness, partitions, and loss of independence influenced, and still influences Polish intellectual life. Even today, the national identity discourses often concentrate on the past. The political traditions and ideas inherited from the Polish-Lithuanian Commonwealth, as well as from the nationalliberation movements of the nineteenth and the early twentieth century still constitute important elements of contemporary Polish political culture.

The military insurrections and mythologized perceptions of liberation struggles were supported by many among the Polish clergy, even when Vatican articulated a geopolitical vision for Europe that conflicted with such support, especially in the nineteenth century. For example, after the publication of the encyclical letter Cum Primum in 1832 by Pope Gregory XVI, many members of the Polish clergy prioritized the ideals of national independence over the loyalty to the Pope (see Gaworski 2019). The discursive partnership between nationalism and 'Polonized' Catholicism emerged. However, even in the nineteenth century, Vatican sometimes fostered Polish independence aspirations, e.g., in the dispute over Kulturkampf between the Prussian state and the Catholic Church. This argument, often viewed as a typical example of the Church-state conflict, was especially significant for the Polish population on the Prussian territory (Blanke 1983). The modernist inclinations of the Prussian state, and the simultaneous anti-Polish and anti-Catholic character of Kulturkampf further galvanized Catholicism with the struggles for national identity and contributed to the creation of foundations for the development of the 'culture war' rhetoric further on. 
Throughout the second half of the nineteenth and at the beginning of the twentieth centuries, distinct conservative milieus grew to prominence in the cities of Cracow, Warsaw, and Vilnius. For example, intellectuals from the Cracow School of History, including professors Józef Szujski and Walerian Kalinka as the leading figures, criticized many social and cultural elements of modernity. They did not aspire to full political independence, and even supported the Habsburgian Austro-Hungarian empire. The autonomy of Cracow and the whole Galicja region probably contributed to this stance, as did the strong Catholic identity of the Habsburg monarchy. However, the intellectual circle of Cracow had strong cultural aspirations. They argued that modern dynamics of change - rapid implementation of industrialism, materialism, processes of secularization - might crush established social orders, traditional family structures and existing moral values. This, in turn, could weaken European political and cultural strength. For Walerian Kalinka, Europe was synonymous with Western Christianity, which he described as 'Latin civilization' (Nowak 2011).

After regaining independence in the aftermath of World War I, a large part of the elites in the Second Polish Republic (1918-1939) still viewed Poland as a protector of the Western Christian world. This time, however, the Bolshevik Soviet Union posed the threat. The concept of independence, again, was inspired by a mythological notion of a civilizational mission. One of the main leaders of the new Polish state, marshal Józef Piłsudski, became a symbol of the military struggle for national independence. He represented neo-romantic nationalism, developed a large army infused with patriotic ideals, and envisioned new Poland based on the heritage of the Polish-Lithuanian Commonwealth. According to Törnquist-Plewa (1992, p. 261) "The fact that Pilsudski embodied values connected to the insurrection myth was crucial for the legitimacy of his power". After a coup d'état in 1926, Piłsudski and his political heirs developed an authoritarian rule embracing a discursive interaction between government-centered nationalism, an enormous emphasis on Poland's sovereignty (especially in opposition to the emergence of two totalitarian states, Soviet Union to the East and Nazi Germany to the West), and a mythical idealization of past military insurrections. Piłsudski's ideology embraced multicultural tolerance in a strong state with a patriotic and obedient society. After his death in 1935, Polish politics witnessed a growing governmental tolerance of ethno-nationalism with anti-Semitic inclinations. Initially, the state did not embrace the ethnic nationalism of the largest oppositional movement, the National Democrats (Endecja). ${ }^{4}$ However, in the 1930s, the romantic and the ethnic versions of Polish nationalism began to merge. In the 1920s and 1930s, Piłsudski's political camp, Sanacja, enjoyed political support from the main conservative party, Stronnictwo Prawicy Narodowej (The Party of the National Right). It supported the strong government, mythologized memories of the Polish-Lithuanian Commonwealth, and favored developing a large army. In other words, the political culture in the interwar period witnessed the development of discursive relationship between elements of 'conservative republicanism', the romantic preoccupation with the fight for freedom, and ethnic nationalism. Pilsudski's ideological and symbolic heritage became important after the fall of Communism in 1989 and has inspired, among others, the leader of Law and Justice, Jarosław Kaczyński.

Polish national identity and political culture, built upon the ideas of independence and 'nationalized Catholicism, ${ }^{5}$ remained significant throughout the rest of the twentieth century, especially during the Second World War and the anti-Communist resistance. After the oppressive era of Stalinism, right-wing movements gradually emerged in the political underground. In the 1960s, some activists and dissidents started to form embryonic oppositional groups stemming from inter-war political movements. Among other things, they published articles about Polish history and patriotic traditions, often in the underground

4 Some politicians presented in the second part of this article, e.g., Robert Winnicki and Krzysztof Bosak, view themselves as direct descendants of the national democratic tradition. They are currently the leading figures of a political party called Confederation Liberty and Independence.

5 It is necessary to distinguish here between the notions of 'Nationalist Catholicism' and 'nationalized Catholicism.' Nationalist Catholicism is a concept much narrower than the notion of nationalized Catholicism, in the same way as Irish Catholicism is nationalized, but not necessarily Nationalist. The "nationalized" Catholicism provides a space for coalitions that do not only consider those with strictly nationalist beliefs, which makes it much more ingrained in the larger society. 
press or in the few Catholic journals tolerated by the regime. A more pronounced 'return' of right-wing ideologies began in the second part of the 1970s and grew throughout the 1980s. According to the social scientist Sordyl (1999, p. 71), the history of political conservatism in post-Communist Poland was largely associated with the formation of Young Poland's Movement since the late 1970s (Ruch Młodej Polski-RMP). The young activists in this organization enjoyed support from the Catholic Church. For example, they organized secret meetings in accommodations provided by the Church. The RMP comprised mainly university students inspired by both the conservative and the nationalist traditions in the Polish political thought. While associated with the famous Solidarity movement, which included various ideological groups, the young activists were consistent in their national conservative discourse and managed to preserve much of its organizational independence throughout the 1980s. ${ }^{6}$ The members of the Young Poland's Movement, some of whom later became professional academics at Polish universities, 'rediscovered' and further developed conservative ideas of Polish national identity, highlighting the importance of political independence, sovereignty and cultural protectionism (Nowak 2011). According to Sordyl, these young intellectuals carried on the tradition of the previously mentioned conservative Cracow School of History. In underground journals, the RMP's members developed a sophisticated ideological polemic with both socialism and liberalism. They articulated antiCommunist, anti-Fascist and anti-liberal values. In 1979, RMP's leader, Aleksander Hall, wrote the following about entire Western Europe, to which Poland seemingly belonged:

The contemporary European civilization is under attack in its cradle-the Old Latin Europe. This civilization fights the Red [communist] and to a smaller extent also Brown [fascist] totalitarianism and anarchism. This civilization fights materialism, which is ruining wealthy societies, and fights the consumerist way of life as well.

(Hall 1979)

Together with other right-wing organizations, the RMP formed discussion clubs, distributed anti-Communist pamphlets and newspapers, published ideological articles, and formed a backbone for future national conservatism in post-Communist Poland. Several contemporary politicians and intellectuals, e.g., Jacek Bartyzel, Marek Jurek, Aleksander Hall, Janusz Korwin-Mikke, began their careers in right-wing opposition of the 1970s and the 1980s. In the last 30 years, many of them affiliated with different political parties and followed diverse ideological paths but remained associated with some form of conservatism; from moderate center-right to more radical positions on the right.

During the parliamentary and presidential elections of 2015 and 2016, national conservatism in Poland experienced unprecedented political success, resulting in a single parliamentary majority for the Law and Justice. After the reelections of 2019 and 2020, Law and Justice constitutes the main power-broker on the Polish right, ruling the country alongside left-wing, liberal, Christian democratic, and agrarian opposition parties. However, the largest opposition party, the liberal Civic Platform, is also located on the political right. In the European Parliament, the Civic Platform belongs to the Christian democratic European People's Party, described by scholars as center-right and moderately right-wing (see, e.g., Bale et al. 2010). The history of Law and Justice and its leaders shows that the party originally competed for the same center-right electorate, and only later moved further towards the political right. In the words of Matthew McManus (2020, p. 188): "The Polish Law and Justice party was founded in 2001 by the Kaczynski brothers, Lech and Jarosław. ( . . ) They began

\footnotetext{
6 The history of the Polish anti-Communist opposition, particularly the Solidarity movement, has received extensive scholarly attention (e.g., Ost 1991; Ash 2002). Solidarity, throughout its history, had millions of members and was led by intellectual and political milieus embracing a large spectrum of ideological stances-from democratic socialism to hardline conservatism. A majority of the opposition cooperated during the second part of the 1970s and throughout the 1980s, united by democratic ideals and a desire to fight against the same enemy. However, in the late 1980s and shortly after the fall of Communism, the ideological divisions became increasingly pronounced. The initial unity between liberal and conservative anti-Communist actors decreased over time. In the mid of the 2000s, the split became somewhat permanent, when the conservative Law and Justice party won the elections. Since then, the political scene was dominated by two parties with anti-Communist heritage taking turns in the role of the ruling party and the opposition—Law and Justice and Civil Platform.
} 
as centre-right politicians ( . . ) appeared little different than other Christian Democrats in Europe". Therefore, the history of national conservatism in post-Communist Poland should be viewed as a process in which ideological sympathies of different political actors changed over time. In contrast, many conservative intellectuals and milieus, including prominent members of the former anti-Communist opposition, continued to advocate a more or less ideologically coherent conservative stance. Many have remained relatively stable in their views for the last forty years.

\subsection{Characterization of Polish National Paleoconservatism}

In 2000, Konrad Wandowicz made a typology of conservatisms operating in Poland between 1989 and 1998. He distinguished between three general lines:

1. Integral conservatism of the reactionary hard-liners, including the monarchists, who criticize the paradigm of liberal representative democracy. This current is associated with Catholic traditionalism and "manifests its disinclination to the changes initiated by the second Vatican Council" (p. 236).

2. Liberal conservatism, comparable with parts of the American Republican Party, combines limited moral traditionalism with economic libertarianism.

3. Neo-conservatism, comparable with Western European Christian democracy and British Conservative Party, which accept the basic principles of the modern state and liberal democracy.

At the beginning of the new millennium, when Wandowicz presented the three types of conservatism, Poland was still in the process of post-Communist transformation. Future ideological developments within the new, democratic republic were still largely unpredictable. Regarding his typology, Wandowicz (2000, p. 237) stated that: “One cannot maintain that these trends will become the persistent orientations in the Polish conservatism, because the very existence of conservatism as an independent political current/movement in Poland has not been settled." We argue that Wandowicz's typology may be extended with a fourth category, particularly applicable to contemporary national and social conservatism. This current is strongly associated with Christian values and similar to the ideas and values of the so-called American Christian Right, and paleoconservatism, another tradition from the United States. American paleoconservatism developed in a different geopolitical context, e.g., mainly in the southern states of the US, in opposition to the growth of neo-conservatism within the Republican party and from dissatisfaction with the US foreign policy. However, American paleoconservatism has interesting contextual and ideological parallels to the Polish case. These parallels may be related to: (1) an emergence of right-wing opposition to mainstream conservatism (including neoconservatism, associated generally with the center-right politics, viewed as too moderate); (2) the philosophical and ideological content, focusing on the need to strengthen and defend national and civilizational identities; and (3) strong intellectual roots of this particular tradition within the history of conservatism. 'Ideological transfers' between the American and Polish political right were and are relatively frequent. Conservative intellectuals and milieus in Poland refer often to their American counterparts and translate their works. ${ }^{7}$ The term of 'paleoconservatism' should be transferred carefully and used with relevant contextual provisions. However, we argue that the parallels are not only sufficient but relevant enough to justify our use of this concept in the Polish context, as it allows for framing the ideological developments discussed in this article.

Williamson (2001) described the paleoconservative system of ideas as follows:

\footnotetext{
7 Among American intellectual paleoconservative publications translated into Polish one may find, e.g., Paul War and Democracy Gottfried's (Gottfried 2012) (translated in 2014 as Wojna i demokracja) and Richard M. Weaver's classical work from 1948, Ideas Have Consequences (Weaver 1948) (translated in 2010 as Idee maja konsekwencje). Polish conservative scholars who wrote about ideas of American paleoconservative intellectuals include Bartyzel (2011); Kucharczyk (2012); Koronacki (2015). Additionally, one of the main intellectual platforms for American paleconservatives is the Rockford Institute, co-founded in the 1970s by a Polish émigré, the novelist and publicist Leopold Tyrmand. The institute's main magazine, Chronicles, was edited by Tyrmand in the 1980s.
} 
Paleoconservatism is the expression of rootedness: a sense of place and of history, a sense of self derived from forebears, kin, and culture-an identity that is both collective and personal. This identity is missing from the psychological and emotional makeup of leftists of every stripe-including "neoconservatives. (... ) The left $(\ldots)$ is and always has been homeless itself: men and women without a country, without a people, without a history-without God".

Paleoconservatism emphasizes the fundamental role of Christianity, not only in Western cultural identity but also in the Western political and legal system. This cannot function properly without being guided by religious and traditional moral principles. Religion, in this perspective, is not only an important element of socio-political framework as many moderate conservatives and Christian democrats would say. Religion is the very heart and soul of a truly Western way of life and, as such, needs to be defended from civilizational threats. In an article on the relationship between Christianity and the judicial system, Presser (2001) argued that paleoconservative thinkers follow the approach of Edmund Burke, the 'founding father' of conservatism. The role of a good government is to introduce good laws, which ought to be based on Judeo-Christian understanding of the natural law. This way of thinking embraces the notion of 'moral politics', which leaves little space for ideological compromises. A nation's identity and culture are not seen as changeable and contextual. Instead, they are primarily viewed in terms of natural/moral versus unnatural/immoral. In this context, matters such as LGBTQ+ rights, abortion, national identity, family values and/or multiculturalism are simultaneously politicized and moralized. Ideological opposition may easily spark a 'culture war', as manifested in present-day Poland. Since Polish conservative actors, just like the American paleoconservatives and/or Christian Right, believe in a discursive and morally grounded unity between culture, religion, politics, and law, as well as in a fundamental role of sovereignty in a nation's political life, we wish to label this ideological current as Polish national paleoconservatism. Many Polish politicians, supported by prominent traditionalist intellectual milieus, argue for moral and sovereign politics, independent from any external pressures, e.g., from the EU. We will later show, using conflicts around the representations of the rainbow, that Polish national paleoconservatism has several characteristics that justify the use of that term. These include (1) biopolitical, religiously and historically grounded organic unity; (2) nationalized perception of Catholicism; (3) centrality of cultural and identity politics; (4) discursive interactions between political leaders and prominent intellectual milieus; (5) moralizing political discourse with a 'civilizational' mission; and (6) paternalist redistributive welfare policies. These elements are strongly interconnected and together constitute the contemporary national paleoconservatism in Poland.

(1) Polish national paleoconservatism is characterized by an essentialist conceptualization of the Polish nation as a biopolitical, historically and religiously grounded organic unity, existing within a larger cultural framework of the Occident. Membership in this unity is not based on a liberal and civic understanding of a community. Instead, the main source of Occidental cultural identity lies in national rootedness, kinship, traditional custom, and a particular role reserved for Christianity. In such cultural sense, Poland is seen as truly Western, due to its devotion to Christian (sometimes depicted as Judeo-Christian) identity and heritage. In contrast to the intellectual legacy of the European Enlightenment as well as the technological, economic and material achievements, the spiritual and cultural heritage makes the Occident truly Occidental, and Poland truly Polish.

(2) Polish national paleoconservatism corresponds with the nationalized perception of Catholicism, manifested discursively in the image of Polak-Katolik ('a Pole = a Catholic,' see Koseła 2003; also Porter-Szúcs 2011). This conservatism allows voices that delicately and cautiously oppose the Holy See. Such opposition was not only manifested historically, but also recently, with regards to the humanitarian duties towards refugees, emphasized by Pope Francis. To oppose the external pressure of the European plan for sharing refugees, many paleoconservative Catholics were ready 
to disobey the Pope (for more on the issue of responses to the refugee crisis, see Krotofil and Motak 2018). In this context, one may argue for a discursive symbiosis between tradition-oriented culture, political use of mythologies, and the concept of power. Political and religious authorities in Polish history have occasionally used "ideals embedded in the myths ( ... ) using the power of myths. The Catholic Church used for instance the miracle myth to strengthen the link between Polishness and Catholicism and its own authority" (Törnquist-Plewa 1992, p. 261). That does not mean that the Catholic Church in Poland differed from the Holy See in its theological doctrine; it only hints on a nationalized understanding of Catholicism within Polish political culture, particularly in the conservative political thought.

(3) Polish national paleoconservatism focuses on cultural and identity politics (not only those related to Catholicism) involving political uses of myths. We agree with Zarycki et al. (2017), who posit that culture is an exceptionally important component of Polish politics. The authors discuss the historical importance of the distinction between the cultural and economic capital. The stability, coherence and power of the Polish networks of Intelligentsia are based on the large amount of elitist cultural capital; a specific habitus of a 'cultured person'. The members of Polish intelligentsia, historically, viewed themselves as descendants of the values presented by PolishLithuanian nobility. Since the loss of independence in 1795, the Polish elites lacked access to political power and economic resources. Instead, these elites relied heavily on participation in informal intellectual circles. They maintained and developed cultural potential and Polish identity as writers, scholars, artists, and members of the clergy. Even in the Second Polish Republic, "after 1918, the political scene and the field of power $(\ldots)$ appeared to be dominated not so much by professional politicians and intellectuals as in the West but by members of the intelligentsia" (Zarycki et al. 2017, p. 367). The political ideals of the Intelligentsia associated Polishness with the past, the political and cultural heritage, mythologized self-images, and Catholicism.

(4) Polish national paleoconservatism is rooted in a tradition of discursive interactions between political leaders and prominent intellectual milieus, often associated with the country's main universities. As noted above, intelligentsia was, and still is, a backbone of Polish political life. Conservative intellectuals, including members of the clergy, provide both ideological content and intellectual legitimacy to today's discourses embodied by parties on the political right, including in particular, but not exclusively, fractions of Law and Justice. For example, many academics associated with the Jagiellonian University and the Catholic University of Lublin play vital political roles. Many professors in Cracow and Lublin, mainly within humanities and social sciences, support the government as politicians, political advisors, or public commentators. Many of these professors published monographs on the state of Polish and European politics and argued for a return to traditional social values to defend Western civilizational identity. It may be interesting to list some of the most recent publications in order to illustrate the topics/concepts that they discuss: Legutko (2016) The Demon in Democracy: Totalitarian Temptations in Free Societies, Jaroszyński and Rolstone (2019) Europe: Civilizations Clashing: From Athens to the European Union; Kucharczyk (2015) Christianitas from the cradle to the crisis (Christianitas—od rozkwitu do kryzysu); Bartyzel (2016) The Right-Nationalism-Monarchism (Prawica-Nacjonalizm-Monarchizm); Szczerski (2017) European Utopia-The Crisis of European Integration and the Polish Initiative of Overhaul (Utopia europejska. Kryzys integracji I polska inicjatywa naprawy); Nowak and Deszczyńska (2018) Church guarding Polish independence (Kościół na straży polskiej niepodległości); Roszkowski (2020) Revolt of Barbarians. 105 questions about the future of our civilization (Bunt barbarzyńców. 105 pytań o przyszłość naszej cywilizacji). These publications, and many others, are a vital part of the intellectual discourse of the political right.

(5) Polish national paleoconservatism develops a highly moralizing political discourse concerning the 'civilizational' mission of Poland, both in terms of politics and culture. 
The European Union's criticism of events that unfold in today's Poland, related to, e.g., the rule of law or LGBTQ+ rights, is perceived not only as ideologically wrong but also morally inappropriate. Poland should be a truly independent and internationally important nation-state and should be able to oppose any dictate from the EU. In fact, Poland may even show the West how to regain its Western identity and heritage. The Polish state should, thereby, play a more prominent role in European politics and contribute to the protection of other nations' sovereignty against federalist tendencies within the EU. Polish voices on cultural and moral issues should be heard because these voices are based on 'natural law' and, therefore, are morally right. With regards to abortion, LGBTQ+ rights and family values, the liberalized and secularized Europe should return to 'normality.' In an interview for the New Oxford Review, Ryszard Legutko elaborated how the concept of 'freedom' is used and misused in contemporary European Union:

I think freedom has ceased to be a highly valued commodity. What is happening is that some groups demand certain privileges, often called "rights," and other groups seem favorable to these demands because they see in them a vehicle for constructing a new society compatible with their outrageous ideologies. When we see, for example, privileges granted to homosexuals, including the right to marry and adopt children - rather unusual privileges, to be sure-we mistake it for the growth of freedom in general.

(Lusch 2017, p. 25)

(6) The contemporary version of national paleoconservatism in Poland is preoccupied with redistributive welfare policies, generally associated with the ideological left, but skewed towards the paternalistically understood family. Flagship among these policies is the $500+$ child benefit program, supporting each family every month with 500 PLN (approximately $€ 120$ ) for each child. Furthermore, the redistributive perspective leads to the following measures: lowering the age of retirement; financial subventions for elderly people to cover the costs of medication; the program entitled Mieszkanie+ (Flat+) aimed at supporting young families wishing to get their first home; increased welfare intervention in education as well as financial governmental support for promoting domestic tourism. Some of these socio-economic policies, especially the $500+$ program, proved to be successful and generated substantial public support for the government. ${ }^{8}$ The state's welfare orientation is expressed in family politics, encouragement of childbirth, an increase in the living standards among the entire national-cultural body. In the words of Shields (2019, p. 664), "Polish capitalism channels the social conservatism, Catholicism and commitment to higher welfare state spending in contrast to its preceding neoliberal transition version". The Law and Justice and the party's leader, Jarosław Kaczyński, have continuously emphasized such 'solidarity'. This idea is related to the previously discussed preoccupation with independence and freedom in Polish political culture. Jarosław Kaczyński captured that relation with the following words:

We have a great goal. This great goal is to make Poland, our homeland, a country equal to our neighbors to the West in terms of economic development, quality of life, while maintaining its identity, its values, its faith, that is, its freedom.

(quoted after Shields 2019, p. 663)

The state's extensive welfare spending after 2015 may be viewed as populist tactics aimed at increasing the popularity of Law and Justice, and as maneuvers to outflank the left-wing parties on economic policies. However, these actions have a clear ideological dimension as well. We agree with the social scientist McManus (2020, pp. 206-7), who argues that a strong sense of cultural attachments in several East-Central European states,

8 According to the World Bank, the 500+ program has had a significant impact on the reduction of child poverty since 2016 (Shields 2019, p. 663). 
including Poland, involves a sense of socio-economic obligations. Working for the good of national polity means ensuring a certain quality of life for all members of that polity. This leads, however, to the assumption that a national community cannot allow extensive immigration and cultural pluralism, since that could deplete the resources allocated for the ethnically-understood nation. Furthermore, even within the framework of a nation, governmental support towards the cultural sector is limited. Resources may be given to cultural institutions and activities that protect and promote a 'true and morally correct' Polish culture. Therefore, there is little space for financial support towards progressive and/or secular cultural productions. Public spending of the current Polish government is, in general, clearly permeated by a national paleoconservative dimension.

\section{Diffusion of Polish National Paleoconservatism in the 2010s}

As we aimed to show above, Polish national paleoconservatism has well-established foundations in the history of Polish political culture. However, up till 2010s, this model of conservatism did not have favorable conditions, and had not developed into a major political and social force. Although the manifestations of 'culture war', e.g., conflicts over the activities of the traditionalist Radio Maryja since the 1990s and the opposition to Pride Parades in Polish cities since the 2000s, began soon after the fall of Communism, they remained rather fringe in character, especially compared to the 2010s.

In this part of the article, we will argue that only in the 2010s a series of events created favorable conditions for Polish paleoconservatism to expand towards previously unseen levels. Firstly, the collapse of the government and electoral losses of 2007 relegated Law and Justice to the opposition for the next eight years. The volatility of the government between 2005 and 2007 discouraged large parts of society from voting for Law and Justice and created a large-scale phenomenon of the so-called 'negative electorate' for the Civic Platform. This allowed the Civic Platform a continuous hold on the government for the next two full parliamentary terms. During these terms, the Civic Platform ruled on the basis of the so-called "warm water in the tap" politics, without significant ideological or identity-building content (Chapman 2016). This created a vacuum for more programmatic politics after the two terms.

Law and Justice met the needs for stronger ideological identification. The time spent in opposition pushed the party further away from the political center-right. The Smolensk air disaster certainly contributed to the party's direction. On the 10th of April 2010, the Polish governmental plane TU-154 crashed and took the lives of 96 Polish officials, including the President Lech Kaczyński, his wife, and several high-ranking members of Law and Justice, many of whom were viewed as party moderates. This provided the foundational myth for a more radical direction of the party and increased the process of further diffusion of national conservatism and combative narratives among different social groups. During the subsequent presidential campaign, Lech's twin brother, Jarosław, built his campaign rhetoric primarily on the notions of internal and external enemies threatening Poland and Polish identity. That political mythologizations and their power have a long tradition in Polish political culture, may explain, at least partially, the successful, mythologized uses of the Smolensk air disaster in Law and Justice's politics.

The first major sign of the increased diffusion of these values and narratives in the society could have been observed shortly after the crash, when the so-called "defenders of the cross" appeared in Warsaw, the Polish capital (see, e.g., Płonkowski 2012; Żukiewicz and Zimny 2015). A few days after the Smolensk catastrophe, a group of scouts from different organizations spontaneously erected a cross in front of the Presidential Palace to commemorate the victims. Three months later, after the presidential elections won by the candidate of the liberal Civic Platform, Bronisław Komorowski, the president-elect announced his will to move the cross to a different place. As Komorowski pointed out, the cross was of religious character, and while its placement as a symbolic memorial was understandable at the time of national mourning, the Presidential Palace and its surroundings should return to the stately, neutral character. 
Komorowski's wish encountered strong opposition from the environments of Law and Justice, who kept gathering in front of the cross to commemorate the victims on the 10th day of each month. Leading figures of the party, such as Jarosław Kaczyński or Zbigniew Ziobro, accused Komorowski of representing foreign (e.g., Russian) interests, hostile towards Polish history and identity (Gazeta Prawna 2010; WP Wiadomości 2010). This soon prompted the party's supporters to unite and assemble. In mid-July 2010, previously spontaneous guards of individual supporters began to defend the cross from any intervention, turning into an organized guard. The defenders of the cross accused the liberal government of a cover up. Komorowski's wish was perceived as denial of martyrdom status to the victims of the crash, symbolized by the cross. They thwarted the first attempt at moving the cross, which resulted in sustained manifestations of both the supporters and the opponents of the cross until it was successfully moved to the chaplaincy in the Presidential Palace.

The 'fight over the cross,' as it was colloquially called, constituted a nationally visible manifestation of the mythologized and identity-oriented character of Polish national paleoconservatism. It emerged as a significant force not only among the intellectual, political, and ecclesiastical elites but also in the broader society. Supported by intellectual milieus, it was strengthened by the friend and foe dynamic so successfully invoked by both Jarosław Kaczyński and new parties emerging even further to the right.

As we argue, the process of gradual advancement of national paleoconservatism, from an intellectual and ideological framework embedded in the history of Polish political culture to a socio-political force supported by a large part of the electorate, can be exemplified by three cases of the disputes around the representations of the rainbow. In the context of Roman Catholicism, the rainbow symbolizes covenant with God. Yet, in recent years it began to be increasingly viewed as an alien, invasive, and, to those who consider homosexual acts a sin, even offensive symbol due to its use in the LGBTQ+ pride and social movements. The disputes on the presence of this symbol in the public sphere, especially in combination with other religious representations (church, icon, or statue) exemplify well how the values and narratives of national paleoconservatism diffused and took hold on the broader society, and translated into the street language. These disputes show the impact that the electoral success of Law and Justice had on the increasing, rainbow-related tensions. The controversies and disputes constitute neither a single party phenomenon, nor a church-based one. Different actors are involved. National paleoconservative ideals were, and continuously are, expressed by various politicians on the right, by parts of the clergy, by media (e.g., Gazeta Polska; Nasz Dziennik), and by right-wing intellectual milieus (e.g., Arcana). Many of these actors share similar (not always the same) ideological and philosophical ideals, but come from differing positions and with varying agendas. Some work as politicians or are directly supporting particular parties. Others are public commentators and opinion writers. Despite all possible differences and nuances, many actors in contemporary Poland, including intellectual milieus, contribute to social diffusion of Polish national paleoconservatism.

\section{1. "Tęcza" by Julita Wójcik}

At the time of the fight over the cross, in August 2010, Polish artist Julita Wójcik created an installation entitled "Tęcza" ("The Rainbow") during her stay at the House of Creative Work in Wigry. This small village is renowned for its Camaldolese-run church and monastery. Wójcik created a symbolic construction out of steel and paper flowers to support the walls of the complex, which were in a state of disrepair (Culture.pl 2020c).

As a part of the preparation for the Polish Presidency of the Council of European Union, Adam Mickiewicz Institute, one of the leading cultural institutions in Poland, selected three artists to present their work in front of the European Parliament in Brussels, among them Wójcik's The Rainbow (Culture.pl 2020b). The second reiteration was much bigger than its predecessor, encompassing 8 tons of steel, 16,000 artificial flowers, and spanning over $9 \mathrm{~m}$ of height and $26 \mathrm{~m}$ of breadth (Culture.pl 2020c). 
After a few months in Brussels, The Rainbow was transported to Warsaw, where it was refreshed during creative workshops in the Zachęta Modern Art Museum. On the 8th of June 2012, Wójcik installed her structure for the third time in the center of one of the most prominent squares in Warsaw-Plac Zbawiciela (Savior's Square). As Wójcik said in an interview:

The moment, at which The Rainbow appeared, coincided with many events: The Pride Parade was on 2 June 2012, followed right afterwards by the Corpus Christi celebration, and, finally, the opening ceremony of the Euro 2012 football championship. In a way, it [The Rainbow] fits all these events and therefore communicates my main message: that The Rainbow is not socially or politically involved, but is instead free from all sorts of imposed meanings. Simply there-to be beautiful.

\section{(Culture.pl 2020a, own translation)}

However, placed in Warsaw, The Rainbow stirred a lot of controversy. After four months, The Rainbow was anonymously vandalized for the first time. It was reconstructed soon afterwards but suffered firework damage during the New Year's celebrations of 2012/2013, and a few days later, was set on fire for the third time. Although previously The Rainbow was supposed to last until the end of January, the city government decided to postpone its deconstruction until at least the end of the year. This met with the vehement opposition of one of the city councilors from Law and Justice, Olga Johann. ${ }^{9}$ In an interpellation to Hanna Gronkiewicz Waltz, the city president and a member of Civic Platform, Johann wrote:

it should be a symbol indicating that our city is modern and open, and that this is how we promote Polish art. ( . . ) Why is Adam Mickiewicz Institute imposing forms of externalization of our modernity on us?

In the Stalinist period, the Constitution Square was designed in such a way that would make one of the most beautiful churches, the Church of the Holiest Savior, disappear from the cityscape. And now, the church is covered with an installation that might seem nice to some-but does not belong in this place.

I am increasingly afraid that, from the point of view of the native Warsaw resident, the city loses its historic architectural shape and will become a conglomerate of imposed, pseudomodernist ideas from other cities, squeezed in between the beautiful, historical architecture.

\section{(Halicki 2013, own translation)}

Johann's remarks highlighted the emerging involvement of Polish paleoconservatives in the debate around The Rainbow. She disputes the imposition of modernity, from the Stalinist period to the present, building upon the myth of the embattled Church in need of protection. But her words focusing on the Holiest Savior Church illustrate a selective religious perspective, focused on the Catholic presence. Magdalena Mich, the spokesperson of the Adam Mickiewicz Institute, highlighted that there is more than one church at the Savior Square, and that their parishioners seem to accept The Rainbow:

It [The Rainbow] does not occlude and in fact lifts the Church of the Savior. According to the Bible, the rainbow is a symbol of the covenant between the man and God. And this installation connects two churches located on the squarethe Methodist Church with the Church of the Holiest Savior. ( ... ) We even discussed it with the rector of the Holiest Savior Parish, and he had nothing against The Rainbow-actually he was in favor.

(Halicki 2013, own translation)

Olga Johann was a psychologist and a sociologist who, in addition to her political career, worked as an academic lecturer. In 2017, she received a prestigious order from Poland's President Andrzej Duda-The Order of Polonia Restituta. 
And yet, some, such as Jesuit Dariusz Kowalczyk, a professor of theology, dismissed the attempts at keeping The Rainbow apolitical. As he wrote in an article entitled "Noah was not Gay":

The problem is that, in our times, the symbol of the rainbow has been hijacked by the LGBT movement ( . . . ) Online one can read that the "rainbow flag" was designed in 1978 as a symbol of the LGBT movement and, that year, it was used for the first time during the gay parade in San Francisco. One can say that the authors succeeded. Thirty years later, the sign is associated with homosexualism. Regrettably!

For the thousands of years, the rainbow was, and must remain, a symbol of the covenant between the men and God. (... )

I think that the symbol of a rainbow is too beautiful to leave it at the mercy of gay activists.

(Kowalczyk 2013, own translation)

With the notion of "hijacking", Kowalczyk, a prominent member of conservative intellectual milieus with philosophical roots in Cracow, continues the line of thinking focused on the embattlement in the public sphere. The Rainbow is reduced to the symbol for LGBTQ+ movement which, according to the author, cannot be reconciled with Catholicism, and represents a global struggle in which the LGBTQ+ movement is seizing the Christian religious symbols.

Despite such critique, and after the fourth arson attempt at the Rainbow in July 2013, the city management launched a tender for the renovation of the structure (Wyborcza.pl 2013b). The reconstructed Rainbow was ready in early November, only to be burned to the ground a few days later, on the 11th of November, when "Independence March" (Marsz Niepodległości) sweeped through the streets of the capital city. The march, celebrating the Polish Independence Day, turned into violent manifestations that resulted not only in The Rainbow's destruction, but also attacks on the Russian Embassy.

At the end of the march, Robert Winnicki, the president of the National Movement that stood behind the event and had clear roots in the previously mentioned, interwar national democratic movements, said:

I speak to all members of the Independence March Guard: Poland needs you. Work on yourself. Keep it up! Only a leftist dares to raise a hand against the Independence March Guard. No true Pole would do that.

On the Savior Square, the rainbow was burned. I do not condone acts like this, and I do not know who stood behind that. But let us be clear: the symbol of the plague was burned. This symbol poses a grave danger to Poland, this is a symbol of the leftist revolution.

Let us start the national revolution! Not only in Poland, but in the whole of Europe. Off with the Brussels' socialism! ( ... )

For the revolution to achieve its goals, we must continue our march. We must start with ourselves. We must set ourselves these goals: to recover Poland, to recover Europe. We want to create a new type of Pole: engaged, organized, one that has things in order.

$$
\text { (Wyborcza.pl 2013a, own translation) }
$$

Winnicki's speech shows that national paleoconservatism in Poland is not a party phenomenon. Instead, several political parties and groups present themselves as true representatives of values understood in this article as nationally paleoconservative. These different groups emphasize different aspects of paleoconservatism, and so Winnicki, and the National Movement over which he presides, focus primarily on the first feature described above: understanding the nation in biopolitical and organic terms, with a strong notion of kinship, civilizational mission, and an idea that Polish identity is threatened. His words are 
emblematic of the ongoing 'culture war'. The involvement of the National Movement and the events of the Independence March raised the levels of controversy to the national level, with a wide range of voices discussing the meaning of the installation and its repeated demise. In the following days, many people would spontaneously honor the burned structure by kissing it and laying real flowers and Scripture citations on it (The Economist 2013).

In the aftermath of the Independence March, Father Tadeusz Rydzyk, Redemptorist founder and director of the influential media outlets including Radio Maryja, TV Trwam and the daily journal Nasz Dziennik, said:

I have no idea whether someone burned it [The Rainbow] due to ideals, or out of provocation, but such symbols of abnormality should not be tolerated, and should not be funded by the public funding. (...) And that there were brawls is the fault of the police. It is the fault of those ruling in Warsaw. And this rainbow on top of it. It is a disgrace! It is a purposeful act of spitting onto our faith, especially the Catholics. On the Savior's Square! ( . . ) It is a shame that such a beautiful sign of the covenant with God is hijacked, given to people who are ill.

(Fakt 2013, own translation)

As a follow up, the city management doubled down on its efforts to keep The Rainbow at its spot and ordered another renovation at the beginning of 2014. The return of the reconstructed installation was accompanied by regular protests from the National Movement and other right-wing environments, including figures such as Krzysztof Bosak, future presidential candidate from the far-right Confederacy (Kielar 2014; Szeler 2014). The protesters had signs such as "Here is Poland, not Brussels"10 and chanted slogans such as "Homorainbow on the Savior's Square has six colors, as many as the symbol of faggotry. If it would have seven, as a true rainbow, we would not protest" (Gazeta.pl Wiadomości 2014). Some protests were accompanied by exorcisms conducted by father Stanisław Małkowski, known also for exorcising Presidential Palace, after the 2010 Smoleńsk plane crash (Szpała 2015).

In May 2014, another arson attempt was successfully prevented. However, in August 2014, despite the raised protection, The Rainbow was, for the sixth time, set on fire (Wyborcza.pl Warszawa 2014). Soon after that, a prayer protest began during each working day, lasting until late November. The protesters were praying the Angelus Domini, followed by a rosary and finished with a chaplet of Divine Mercy. The protest was initiated by father Jerzy Garda, who, similarly to father Małkowski, was known for his previous involvement in the defense of the cross (Radio Maryja 2014).

The exorcisms and prayer protests highlight the importance of the individual clergymen in turning the intellectual current and political movement of paleoconservative tradition into a grassroot social engagement. The involvement of the individual priests also shows, however, that this is one approach to Catholicism among many in the Polish context, that cannot be generalized onto the entire Catholic Church in Poland. Father Małkowski, formerly the chaplain of the Solidarity movement, actively involved in the opposition to the Communist regime, was repeatedly censured for his public engagement by his superiors. Father Garda, a former missionary known for his conservative social activism, compared the removal of the cross from the front of the Presidential Palace to the involvement of Pharisees in the death of Christ, even though the Warsaw Curia had explicitly accepted the removal (Garda 2010).

The Rainbow was finally deconstructed at the end of August 2015, after going up in flames at the end of 2014. Summarizing the exhibition, Stanisław Ruksza, an art historian, wrote that "the third, Warsaw-based version of the installation ... was one of the most important works of the last years in Poland in terms of the social reception, a litmus test for the changing public mood and the nationalist shift of the parts of society" (Ruksza 2015, own translation). The five years of The Rainbow observed the growing significance of

10 This is a clear example of diffusion, and how the intellectual considerations are translated into the language of the street. 
paleoconservatism in multiple aspects of the Polish public sphere- from the intellectual environments, through the political grouping at both the local and national level, to social engagement at the grassroots level (for the importance of the street-level engagement, see Lipsky 1980; Tocheva 2017). From a predominantly intellectual current, paleoconservatism transformed into a multi-layered phenomenon, with independent adherents, each with their own way of expression. This, together with the growing dissatisfaction with the liberal government, provided the necessary foundations for the largest electoral victory in the history of post-Communist Poland, granting Law and Justice full majority in the parliament. Leading politicians, striving to represent what we describe as national paleoconservatism, received the coercive tools of the government to prove their allegiance to this intellectual tradition. This meant that the use of the representation of the rainbow in the subsequent years would have radically different effects than before, between 2010 and 2015. Two subsequent cases, concerning Black Madonna with the Rainbow Halo, and Christ with the Rainbow Flag, will highlight these shifts in approach.

\subsection{Black Madonna with the Rainbow Halo}

As a part of an Easter Sunday décor in 2019, the St. Dominic Church in Płock put up a big cross with a ribbon painted in white and red, colors of the Polish flag, accompanied by a sign "protect us from the fire of unbelief". Several boxes with signs were placed in front of the cross to exemplify different sins, such as "hate", "contempt" or "greed", but also "gender", "LGBT" and "homodeviations". The exhibition was picked up and broadly publicized, but remained absent in the state-run TVP, Telewizja Polska, reshaped by Law and Justice as a party-aligned tool. The decoration was heavily criticized by media associated with the political opposition for the derogatory tone and in relation to recent accounts of sexual abuse within the Catholic Church in Poland (Lewandowska 2019; Newsweek Polska 2019).

In response, a few days later, a group of activists put up several posters in the vicinity of the church in Plock. The posters would depict the Virgin Mary and Baby Jesus with the rainbow-colored halo. The image was based on the representation of Black Madonna at the monastery Jasna Góra that, as mentioned in the first part of this paper, bears special significance and meaning in the Polish history. However, in the poster, Madonna's golden halo was replaced with a six-colored rainbow. The police quickly identified Elżbieta Podleśna, a known figure from the political opposition, as one of the activists behind the posters. Within the next few days, early in the morning, the police entered her apartment. Podleśna was detained and charged with the violation of religious feelings under article 196 of the Polish Penal Code. A few hours later, Joachim Brudziński, the Minister of the Interior and Administration, in a short tweet, thanked the police for their swift action and detention of the person that "was suspected of profaning the holy image of the Virgin Mary, dear to Poles for many centuries." As he continued, "no fables of freedom and 'toleration' can give the right to hurt religious feelings of the believers," highlighting that the rights of Catholics must be guaranteed, too (Brudziński 2019, own translation). Soon afterwards, the government's spokesperson presented similar argumentation (Onet.pl Wiadomości 2019) and, thereafter, the state-run TV, TVP, engaged in the case. On the one hand, the previous critique of the church decoration by one of the leading newspapers, Gazeta Wyborcza, was presented as an attack on the parish priest. On the other hand, the subsequent activists' action was presented as a profanation committed by the "followers of the LGBT ideology." The parish priest was compared to the blessed Jerzy Popiełuszko, the martyr of the Communist times. A link presented alongside the website post referred the viewer to another article, on acquiescence towards the persecution of Christians (TVP Info 2019b). All three channels from the Polish government presented the uniform vision of the embattled Christianity, which needed unconstrained and rapid defense against "cultural barbarity" (TVP Info 2019a).

This quickly erupted into a widely publicized controversy. The polls indicated that two-thirds of Poles thought that Podlesna's detention was unfounded (Kwolek 2019). Helsinki Committee concluded that the police actions had violated the constitutional 
rule of proportionality. According to this rule, Podleśna should have been summoned to questioning. The response was disproportional, with the police entering her house at 6 a.m., searching the entire house and checking the correspondence, and could be viewed as politically motivated (RP.pl 2019a).

Lawyers seemed more divided on the case. Many of them highlighted that the notion of "religious feelings", and what offends them, was quite vague. As some highprofile attorneys argued, the law was inherently faulty as its subject was too vague to clearly denote what was penalized (Domagalski 2019a, 2019b). The lawyers from the paleoconservatively-inclined Ordo Iuris Institute ${ }^{11}$ held a different opinion. Its president, attorney Jerzy Kwaśniewski, said, highlighting the need for relating Christian morality to law:

The modification of a religiously venerated object, that is, replacing the halo with a six-colored rainbow, a symbol of the LGBT political movement that builds its identity on the sexual behaviour that is deemed "sins crying out to heaven for vengeance" by Christian ethics, seems to qualify for the use of the art. 196 of the Penal Code and both the immediate detection of the perpetrator and the efficient operation of the police deserve praise, especially if one takes into account emerging copy-cats and the subsequent profanations of the icon.

$$
\text { (Domagalski 2019a, own translation) }
$$

Michał Szułdrzyński, a journalist in Rzeczpospolita, one of the leading daily newspapers associated with the moderate right, wrote that the actions of the police should be separated from the attack on the religious feelings of believers. As Szułdrzyński pointed out, the police overreacted towards Podleśna in a way that was unproportioned and bore marks of political oppression, but Podleśna was not without fault either. As he proposed, the Catechism of the Catholic Church clearly stated that while homosexuals should be treated with respect, their actions were morally wrong. While criticizing people and institutions should be allowed, Podleśna and other activists targeted a sacred representation, showing disrespect and lack of tolerance. According to the law, the religious sensitivities should be protected, so Podleśna should have been punished, although in a proportional way (Szułdrzyński 2019).

Not all Catholics in Poland shared Szułdrzyński's views. In an open letter to the Polish Episcopate published by the magazine Więz, lay Catholics from different environments, stated that settling what counts as profanation, desecration or blasphemy is not the role of the state. The lay Catholics highlighted the selective approach of the Episcopate and the state to other clear examples of profanation, like the nationalist conventions at Jasna Góra, propagating content that opposed many Church teachings. They expressed concern with the lack of Episcopate's response to Jarosław Kaczyński, who said that "who raises their hand against the church, raises their hand against Poland", pointing toward the politicization of the Church. Finally, the lay Catholics pointed out that using the rainbow as it had been used in the posters was not wrong in any way (Więź 2019).

Soon afterwards, Stanisław Karczewski, the speaker of the Senate, expressed his surprise with the public outcry. As he said, something similar happened in the past, when a few anti-Muslim activists threw pork into the mosque. The police arrested the activists on the same grounds and there was no public outrage. Mirroring earlier words of Joachim Brudziński, who said that the rights of Catholics must be secured too, Karczewski argued that there are double standards that fail to grant the Catholics in Poland the same levels of protection as other believers (RP.pl 2019c). Some opinion writers agreed with Karczewski.

11 Ordo Iuris Institute is a foundation focused on "studies of legal culture and the spiritual heritage in which the Polish culture is rooted, and their dissemination in the public life and legal system." (See www.ordoiuris.pl/sites/default/files/inline-files/Statut\%20Ordo\%20Iuris.pdf (accessed on 17 December 2020)). It collaborates with many of the leading Polish conservative intellectuals and lawyers, such as its first president Aleksander Stepkowski, professor of law at the University of Warsaw, Tomasz Terlikowski, a well-known publicist with a doctorate in theology, or Bogdan Chazan, professor of gynecology known for controversies around his refusal to conduct legally-sanctioned abortion. Ordo Iuris Institute was responsible for the controversial abortion bill that led to the mass protests in 2016, which was ultimately rejected by the parliament (see Polityka 2016). 
Tomasz Pietryga, publicist of Rzeczpospolita, wrote that no one would dare to impose a rainbow onto a picture venerated by Jews or Muslims. Jarosław Sellin, the Deputy Minister of Culture, would thereafter add that Podleśna was a "professional provocateur", and should not be treated as a victim, given the circumstances (RP.pl 2019b).

Several aforementioned intellectuals expressed criticism towards progressive activists that aimed to provoke debates on the role of religion in Polish society. For example, Ryszard Legutko, a professor of philosophy and a European MP, argued that contemporary 'political correctness' in liberal democracies may conflict with religious feelings that are increasingly disrespected. Legutko stated that, for many people, liberal democracy is a supreme political arrangement and "it is natural that those people want the Church to adapt itself to democratic and liberal standards and practices" (Lusch 2017, p. 26). Such adaptation, however, does not respect the traditional religious feelings, nor the freedom of the Church and its followers.

Many journalists suggested that the strong reaction from the government, prosecution and the police was a political stunt before the forthcoming European Parliamentary elections. Some suggested that it was an effort at mobilizing the electorate of Law and Justice by presenting the party as a strong supporter of the Church (Bartkiewicz 2019). Others pointed out that Brudziński wanted to leave his post as the Minister of Interior, and become a European MP himself (Pietryga 2019).

The case of Black Madonna with the Rainbow Halo showed how the diffusion of the national paleoconservatism peaked during the first parliamentary term, won by Law and Justice. In this term, the notion of the embattlement was not only shared by the government and the parties in the political right but was also supported by the representatives of moderate right, e.g., the opinion writers of Rzeczpospolita. Loyal to Law and Justice, TVP further promoted paleoconservatively-inclined clergy and ignored the letter of lay Catholics that opposed the instrumentalization of religious tradition. The legal interpretations of Ordo Iuris Institute, which could be viewed as the paleoconservative watchdog, were shared by the government and put in practice. Despite the majority of Poles viewing such actions as an overreaction, the situation did not result in any significant protests and proved electorally beneficial for Brudzinski, who received the second-highest vote count in his constituency in the following European Parliamentary elections (Państwowa Komisja Wyborcza 2019). This peak of paleoconservatism in Poland, and the primacy of Law and Justice in representing this political option, resulted in subsequent electoral victories in both the parliamentary and presidential elections of 2019/2020. However, the success of paleoconservatism attracted other political options. In fact, even some members of the political opposition became more open to paleoconservatism, as shown in the case of Christ with the Rainbow Flag.

\subsection{Christ with the Rainbow Flag}

On the night of the 28th to the 29th of July 2020, a group of local activists attached a rainbow flag to a few statues in Warsaw, including the famous figures of Warsaw Mermaid, Nicholas Copernicus, or Christ in front of the St. Cross Church. This action, aimed at highlighting the problem of homophobia in Poland, was accompanied by a manifesto stating that "the city is for everyone" (RP.pl 2020a).

In response, Prime Minister Mateusz Morawiecki wrote on Facebook as follows:

The basic condition for any civilized debate about tolerance is to define the limits of such tolerance. Can we justify any, even the most blasphemous behavior, as a fight for a better vision of the world? Does the end justify the means? Absolutely NOT!

Certain limits have been exceeded. The desecrated figure of Jesus from Krakowskie Przedmieście is not only a religious symbol, but a witness to the dramatic history of the capital city of Warsaw. The same Warsaw that was harmed by people that did not tolerate another vision of the world than their own. 
Each side of the big, ideological dispute of our time that intensifies around the world and which can be likewise observed in Poland, must understand that there are certain unsurpassable limits of the aggression level.

Poland will not make the same mistakes as the West. We all see what brings tolerance toward barbarity.

$$
\text { (RP.pl 2020a, own translation) }
$$

In a similar vein, Cardinal Kazimierz Nycz, the Archbishop of Warsaw, said that:

Profanation of the historic figure of Christ 'Sursum corda' on the Krakowskie Przedmieście in Warsaw induced pain in the believers, parishioners of the St. Cross Church and many residents of the capital city, for whom the figure of the Savior lifting the cross has been the symbol of hope in the most difficult days of the Uprising [of 1944].

(Kołodziejczyk 2020, own translation)

Unlike in the previous two cases, here, the highest figures of both the government and the Polish Episcopate decided to speak up and condemn the activists. Both returned to the notion of embattlement by bringing historical references concerning the events of the Second World War. Morawiecki went even further, with a moralizing reaction reminding of the notion of Antemurale Christianitatis. Namely, Morawiecki contrasted the Polish actions with the actions of the West which, according to him, tolerate "barbarity," and lead to catastrophic consequences in the global ideological dispute.

However, this time more actors took part in the discussion. In the 2019 elections, a hitherto minor faction of Law and Justice, Solidary Poland, doubled its parliamentary mandates and became critical to the parliamentary majority of Law and Justice. This allowed Zbigniew Ziobro, the leader of Solidary Poland and the Minister of Justice, to pronounce his ambitions at seizing the primacy among the political right. To this end, Sebastian Kaleta, Ziobro's ministerial deputy, openly criticized placing the rainbow flags on the Warsaw statues. As Kaleta stated, this action was an obvious crime under the art. 196 of the Polish Penal Code, used against Elżbieta Podleśna, and asked the prosecution office to investigate this.

A new coalition of various far-right parties, Confederation Liberty and Independence, aiming at the similar electorate to that of Law and Justice, also noted an increase in electoral votes in both the parliamentary and presidential elections. In response to the events of the 28th/29th of July, Krzysztof Bosak, the party's presidential candidate, said: "It must be clearly said that the LGBT flag is not a symbol describing a political program of LGBT movement, but it is an affirmation of sin. That is why it is controversial for Christians. If something like that is hung on the statue of the Savior, then we do not condone it" (Do Rzeczy 2020).

More surprisingly, even Rafał Trzaskowski, one of the leaders of the liberal opposition, rejected the actions of the LGBTQ+ activists. As he wrote:

I would like to emphasize that no statue was destroyed, but I have to put it clearly: putting any flag on the symbolic figure of Christ, one of the symbols of the Warsaw Uprising, is, to my understanding, an unnecessary provocation.

In particular, on the day before the anniversary [of the Uprising], when we should talk about respect for all. In my opinion, this action, carried out in this special time, may offend religious feelings of many people.

(RP.pl 2020b, own translation)

The subsequent defeats in a number of elections, despite broad coalitions of the opposition parties, required a change in approach. Trzaskowski's remarks might have indicated such a change. The alteration of his tone suggested a certain accommodation of the paleoconservative principles on the side of the opposition.

The case of Christ with the Rainbow Flag indicated the peak of diffusion of national paleoconservatism in Poland. Most major political voices began to at least change their 
rhetoric to adapt to that political option. In 2020, the political scene in Poland became saturated with different parties striving for the right to represent the paleoconservatively inclined voters. However, while this may be the source of strength of national paleoconservatism at the moment, it may underpin increasing governmental volatility in the future, both due to the internal fights within Law and Justice, as well as the threatening influence of both the opposition and the even more radical Confederation. This is how an intellectual current that reemerged in the 1970s, thanks to the significant growth in the early 2010s, became the major political force in the late 2010s.

\section{Conclusions}

In a monograph entitled Philosophy and Romantic Nationalism - The Case of Poland, Walicki (1982, p. 1) wrote: "Polish intellectual history is almost entirely unknown in the West and interest in it is almost non-existent". In the forty years that passed since the publication of these words, a lot has changed. After the fall of the Iron Curtain, Polish intellectuals have increasingly participated in Western scholarly frameworks and projects. Therefore, the ideas and perspectives, as well as intellectual traditions of the Polish scholars and thinkers, are no longer unknown in the West. However, the intellectual roots and historical development of Polish conservatism still remain understudied and deserve much more analytical attention. ${ }^{12} \mathrm{~A}$ lot is today written and said about Polish right-wing politics, often associated with the government led by Law and Justice. However, little scholarly or journalistic attention is paid to the conservative intellectual milieus, which provide ideological content as well as academic legitimacy to concrete politics and inspire social engagement at the grassroots level.

This article aimed to shed light on the right-wing intellectual traditions and milieus within Polish political culture, in the past and today. We argued that contemporary conservative and nationalist ideas and politics in Poland need to be (a) historically contextualized, and (b) more accurately defined and conceptualized. The concept of Polish 'national paleoconservatism' captures the current system of ideas and values articulated by prominent right-wing intellectuals. This conservatism is further socially diffused by political and cultural practices, such as policies of the current government, activities of various political parties, cultural organizations and conservative media. Some intellectual figures at Polish universities and members of the clergy actively participate in articulation and social diffusion of the national paleoconservative discourse.

Polish national paleoconservatism is an important part of the ongoing 'culture war' that was exemplified here with three cases of the polarized perception of meanings associated with the symbol of the rainbow. The first case, of controversies around the artistic representation of the rainbow created by Julita Wójcik, showed the reemergence and growth of national paleoconservatism as a significant political and social force in Poland during the years 2010-2015. The subsequent electoral victories of Law and Justice created favorable conditions for this ideological current, as demonstrated in the case of the Black Madonna with the Rainbow Halo. Finally, the success of national paleoconservatism resulted in the saturation of the political scene in the period 2019-2020. This saturation, in turn, led to the emergence of rivalling fractions both within and outside of Law and Justice and even pushed the political opposition toward partially paleoconservative rhetoric.

At the moment of the submission of this article, Jarosław Kaczyński gave an interview to Rzeczpospolita, one of the leading daily newspapers in Poland. This was a rare form of public outreach for the Law and Justice leader. The interview, advertised on the first page with a bold headline "Europe must respect our identity and our culture", discussed several recent 'crises' of the current government. The three years of supposedly uninterrupted rule ahead of the next election cycle were disrupted by the pandemic, internal rivalry, rejection of party discipline and MP resignations, mass popular outcry after the Constitutional

12 To date, the most significant (and perhaps the only) substantial monograph in English analyzing the history of Polish conservative thought in the nineteenth and twentieth century, Rett R. Ludwikowski's: Continuity and Change in Poland: Conservatism in Polish Political Thought, published three decades ago, in 1991 (Ludwikowski 1991). 
Tribunal verdict restricting abortion, and the Polish threats of vetoing the EU budget. The interview showed that the current status of Polish conservatism is at a crossroads. On the one hand, Kaczyński announced further changes in the judicial system, discussed the significant role of Poland in returning Europe from the brink of dissolution and expressed his confidence in the sustained political mandate for such actions, especially from the political right. On the other hand, Kaczyński admitted loss in social support due to the explosion of public frustration and the internal problems of the governmental coalition, and nodded towards the possibility of retirement within the next four years (Kolanko 2020).

The Polish paleoconservative model is unique in its established intellectual tradition and rootedness in Polish history, independence struggles, and the resulting specificity of the Catholic Church in Poland. This said, however, the model could aid further comparative research on analogical developments in other countries. For example, the political ideas within, and intellectual exchange between the Polish and American right may point toward similarities and transfers between the two countries. The development curve described in the second part of this article may be compared to the growth of right-wing movements in other European countries, such as Sweden, Denmark, or Austria. Finally, the characteristic relation between the national identity and the Catholic Church in Poland may be compared with countries sharing similar historical conditions, e.g., Ireland.

Author Contributions: The authors equally contributed to this article at all stages of the development and writing process. All authors have read and agreed to the published version of the manuscript.

Funding: This research received no external funding.

Institutional Review Board Statement: Not applicable.

Informed Consent Statement: Not applicable.

Acknowledgments: We want to thank Katarzyna Bobrowicz at Lund University for her extensive help with language editing. We would like to express gratitude to Barbara Törnquist-Plewa at Lund University, who connected the authors and provided us with academic and motivational support. Finally, we would like to thank the Global Christianity and Interreligious Relations Seminar at Lund University, as well as the Political and Public Theology Reading Group at the University of Edinburgh for their helpful feedback, comments, and suggestions.

Conflicts of Interest: The authors declare no conflict of interest.

\section{References}

Alvis, Robert E. 2018. The Catholic Church in Polish History: From 966 to the Present. By Sabrina P. Ramet. Journal of Church E State 60: 541-43. [CrossRef]

Ash, Timothy Garton. 2002. The Polish Revolution: Solidarity. Yale: Yale University Press.

Bale, Tim, Seán Hanley, and Aleks Szczerbiak. 2010. 'May Contain Nuts'? The Reality behind the Rhetoric Surrounding the British Conservatives' New Group in the European Parliament. The Political Quarterly 81: 85-98. [CrossRef]

Bartkiewicz, Artur. 2019. Bartkiewicz: Matka Boska w tęczowej aureoli: PiS nie straszy, PiS mobilizuje. RP.pl. Available online: https: / / www.rp.pl/Komentarze/190509514-Bartkiewicz-Matka-Boska-w-teczowej-aureoli-PiS-nie-straszy-PiS-mobilizuje.html (accessed on 17 December 2020).

Bartyzel, Jacek. 2011. Legitymizm: Historia i teraźniejszość. Wrocław: Fundacja “Virus Nobilitat".

Bartyzel, Jacek. 2016. Prawica-Nacjonalizm-Monarchizm. Radzymin: Von Borowiecky.

BBC News. 2020. Poland LGBT: Diplomats from 50 Countries Call for End to Discrimination. Available online: https:/ /www.bbc.com/ news/world-europe-54317902 (accessed on 17 December 2020).

Blanke, Richard. 1983. The Polish Role in the Origin of the Kulturkampf in Prussia. Canadian Slavonic Papers/Revue Canadienne des Slavistes 25: 253-62. [CrossRef]

Bodziony, Jakub. 2020. Kłamstwa PiS-u na temat UE szybko się na nas zemszczą. Kultura Liberalna, April 17.

Borén, Thomas, Patrycja Grzyś, and Craig Young. 2020. Intra-urban connectedness, policy mobilities and creative city-making: National conservatism vs. urban (neo)liberalism. European Urban and Regional Studies 27: 246-58. [CrossRef]

Brubaker, Rogers. 2017. Between nationalism and civilizationism: The European populist moment in comparative perspective. Ethnic E Racial Studies 40: 1191-226. 
Brudziński, Joachim. 2019. Dziękuję @PolskaPolicja za sprawną akcję z wytypowaniem i zatrzymaniem osoby podejrzewanej o profancję świętego od wieków dla Polaków wizerunku Matki Bożej. [ . . . ] Twitter. Available online: https://twitter.com/ jbrudzinski/status/1125351071692533760?ref_src=twsrc\%5Etfw (accessed on 17 December 2020).

Casanova, José. 1994. Public Religions in the Modern World. Chicago and London: The University of Chicago Press.

Chapman, Annabelle. 2016. Close-Up: Donald Tusk. Berlin Policy Journal. July 6. Available online: https://berlinpolicyjournal.com/ close-up-donald-tusk/ (accessed on 17 December 2020).

Culture.pl. 2020a. The Rainbow-Julita Wójcik. Available online: https://culture.pl/en/work/the-rainbow-julita-wojcik (accessed on 18 November 2020).

Culture.pl. 2020b. Fossils and Gardens. Available online: https://culture.pl/pl/wydarzenie/fossils-and-gardens (accessed on 18 November 2020).

Culture.pl. 2020c. Julita Wójcik, ‘Tęcza'. Available online: https://culture.pl/pl/dzielo/julita-wojcik-tecza (accessed on 18 November 2020).

Do Rzeczy. 2020. Bosak: Nie ma na to naszej zgody. Available online: https://dorzeczy.pl/kraj/148896/bosak-nie-ma-na-to-naszejzgody.html (accessed on 17 December 2020).

Domagalski, Marek. 2019a. Dobra osobiste a granice krytyki kościoła. RP.pl. Available online: https://www.rp.pl/Dobra-osobiste/30 5089891-Dobra-osobiste-a-granice-krytyki-kosciola.html (accessed on 17 December 2020).

Domagalski, Marek. 2019b. Dariusz Pluta: Krytyka Kościoła i wierzacych wymaga wyczucia. RP.pl. Available online: https: //www.rp.pl/Dobra-osobiste/305089960-Dariusz-Pluta-krytyka-Kosciola-i-wierzacych-wymaga-wyczucia.html?cid (accessed on 17 December 2020).

Drolet, Jean-François, and Michael C. Williams. 2018. Radical conservatism and global order: International theory and the new right. International Theory 10: 285-313. [CrossRef]

Dutceac Segesten, Anamaria. 2011. Myth, Identity, and Conflict: A Comparative Analysis of Romanian and Serbian Textbooks. Playmouth: Lexington Books.

Eatwell, Roger, and Matthew Goodwin. 2018. National Populism: The Revolt Against Liberal Democracy. London: Pelican Books.

Enyedi, Zsolt. 2016. Paternalist populism and illiberal elitism in Central Europe. Journal of Political Ideologies 21: 9-25. [CrossRef]

Erel, Umut. 2018. Saving and reproducing the nation: Struggles around right-wing politics of social reproduction, gender and race in austerity Europe. Women's Studies International Forum 68: 173-82. [CrossRef]

Erlanger, Steven, and Marc Santora. 2018. Poland's Nationalism Threatens Europe's Values, and Cohesion. New York Times, February 21.

Fakt. 2013. Rydzyk o tęczy: Symbole zboczeń nie powinny być tolerowane. Fakt. Available online: https://www.fakt.pl/wydarzenia/ polityka/rydzyk-o-teczy-symbole-zboczen-nie-powinny-byc-tolerowane/kvsfrvr (accessed on 17 December 2020).

Garda, Jerzy. 2010. ks. Jerzy Garda: 16 września 2010 roku wszystko się dopiero zaczęło, in W Obronie Krzyża. Available online: https: / wobroniekrzyza.wordpress.com/wszystko-sie-dopiero-zaczelo-\%e2\%80\%93-wypowiedz-telefoniczna-obecnegopod-kordegarda-ks-jerzego-gardy-dla-naszej-strony-z-godziny-10-39/ (accessed on 17 December 2020).

Gaworski, Janusz. 2019. Niepodległa bo Katolicka? O Kościele Czasu Zaborów. Sulejówek: Muzeum Józefa Piłsudskiego w Sulejówku.

Gazeta Prawna. 2010. Kaczyński: Jeżeli Komorowski usunie krzyż, wiadomo kim jest. Available online: https://www.gazetaprawna. pl/wiadomosci/artykuly/436613,kaczynski-jezeli-komorowski-usunie-krzyz-wiadomo-kim-jest.html (accessed on 17 December 2020).

Gazeta.pl Wiadomości. 2014. Narodowcy przyszli pod Tęczę. Rzucali w nią jajkami. Available online: https:/ /web.archive.org/web/ 20140502153848/http:/wiadomosci.gazeta.pl/wiadomosci/1,114883,15888850.html (accessed on 17 December 2020).

Godzisz, Piotr, and Marta Rawłuszko. 2018. Responding to Anti-LGBT Hate Crimes in Poland: One Step Forward, Two Steps Back? In Running Through Hurdles: Obstacles in the Access to Justice for Victims of Anti-LGBTI Hate Crimes in Europe. Edited by Piotr Godzisz and Giacomo Viggiani. Warsaw: Lambda Warsaw, pp. 221-43.

Gottfried, Paul. 2012. War and Democracy. London: Arktos Media.

Graff, Agnieszka. 2010. Looking at Pictures of Gay Men: Political Uses of Homophobia in Contemporary Poland. Public Culture 22: 583-603. [CrossRef]

Grzebalska, Weronika, and Andrea Pető. 2018. The gendered modus operandi of the illiberal transformation in Hungary and Poland. Women's Studies International Forum 68: 164-72. [CrossRef]

Halicki, Piotr. 2013. Radna PiS przeciwko tęczy na placu Zbawiciela. 'Zasłania kościół'. Wiadomości Onet.pl. Available online: https:/ / web.archive.org/web/20131111190834/http:/ / wiadomosci.onet.pl/warszawa/radna-pis-przeciwko-teczy-naplacu-zbawiciela-zaslania-kosciol/ghtzb (accessed on 17 December 2020).

Halikiopoulou, Daphne, and Tim Vlandas. 2019. What is new and what is nationalist about Europe's new nationalism? Explaining the rise of the far right in Europe. Nations \& Nationalism 25: 409-34. [CrossRef]

Hall, Aleksander. 1979. Europa, ale jaka? Bratniak—Pismo Ruchu Młodej Polski 19: 5-7.

Hockenos, Paul. 2010. Central Europe's Right-Wing Populism. Nation 290: 18-21.

Hunter, James Davison. 1991. Culture Wars: The Struggle to Define America. New York: Basic Books.

Jaroszyński, Piotr, and Lindael Rolstone. 2019. Europe: Civilizations Clashing. Bern: Peter Lang.

Jedlicki, Jerzy. 1999. A Suburb of Europe: Nineteenth-Century Polish Approaches to Western Civilization. Budapest: Central European Press. 
Kielar, Adam. 2014. Liderzy Ruchu Narodowego zatrzymani za blokadę odbudowy tęczy. Polityka Warszawska. Available online: http:/ / politykawarszawska.pl/a/578 (accessed on 17 December 2020).

Kolanko, Michał. 2020. Patrzymy na UE realistycznie-Zachodzą w niej złe procesy. Rzeczpospolita, December 21, A4-A5.

Köllner, Tobias, ed. 2019. Orthodox Religion and Politics in Contemporary Eastern Europe. On Multiple Secularisms and Entanglements. London and New York: Routledge.

Köllner, Tobias. 2020. Orthodox religion, politics, secularity and the introduction of new festive days in contemporary Russia. The case of the day of family, love, and faithfulness. Etnografia e Ricerca Qualitativa 2020: 119-41. [CrossRef]

Köllner, Tobias. 2021. Religion and Politics in Contemporary Russia. Beyond the Binary of Power and Authority. London and New York: Routledge.

Kołodziejczyk, Karolina. 2020. Warszawa. Pomnik Jezusa z tęczową flagą. Jest oświadczenie kardynała Kazimierza Nycza. WP Wiadomości. Available online: https:/ / wiadomosci.wp.pl/warszawa-pomnik-jezusa-z-teczowa-flaga-jest-oswiadczenie-kardynalakazimierza-nycza\$-\$6537412195722881a (accessed on 17 December 2020).

Korolczuk, Elżbieta. 2017. "Worse than communism and nazism put together": War on Gender in Poland. In Anti-Gender Campaigns in Europe: Mobilizing Against Equality. Edited by Roman Kuhar and David Paternotte. London and New York: Rowman \& Littlefield International, pp. 175-94.

Koronacki, Jacek. 2015. Amerykański Konserwatyzm na Progu XXI Wieku. Radzymin: Von Borowiecky.

Koseła, Krzysztof. 2003. Polak i Katolik. Splatana Tożsamość. Warszawa: Instytut Filozofii i Socjologii PAN.

Kováts, Eszter. 2016. The Emergence of Powerful Anti-Gender Movements in Europe and the Crisis of Liberal Democracy. In Gender and Far Right Politics in Europe. Edited by Michaela Köttig, Renate Bitzan and Andrea Petö. Cham: Palgrave Macmillan, pp. 175-89.

Kováts, Eszter. 2018. Questioning Consensuses: Right-Wing Populism, Anti-Populism, and the Threat of 'Gender Ideology.'. Sociological Research Online 23: 528-38. [CrossRef]

Kowalczyk, Dariusz. 2013. Noe nie był gejem. Idziemy. Available online: http://idziemy.pl/komentarze/noe-nie-byl-gejem/ (accessed on 17 December 2020).

Krotofil, Joanna, and Dominika Motak. 2018. A critical discourse analysis of the media coverage of the migration crisis in Poland: The Polish Catholic Church's perception of the "migration crisis". Scripta Instituti Donneriani Aboensis 28: 92-115. [CrossRef]

Kucharczyk, Grzegorz. 2012. Russell Kirk. Myśl Polityczna Amerykańskiego Konserwatysty. Warszawa: Prohibita.

Kucharczyk, Grzegorz. 2015. Christianitas—od rozkwitu do kryzysu. Warszawa: Prohibita.

Kwolek, Grzegorz. 2019. Sprawa Matki Boskiej z tęczową aureola. Polacy krytycznie o zatrzymaniu aktywistki. RMF24. Available online: https: / / www.rmf24.pl/fakty / polska/news-sprawa-matki-boskiej-z-teczowa-aureola-polacy-krytycznie-o-z,nId,2990 149 (accessed on 17 December 2020).

Legutko, Ryszard. 2016. The Demon in Democracy: Totalitarian Temptations in Free Societies. New York: Encounter Books.

Lewandowska, Anna. 2019. (Nie)sława Grobu Pańskiego w płockim kościele na Górkach. Bo "nawołuje do nienawiści". A do tego kłótnia, oskarżenia. Wyborcza.pl Płock. Available online: https://plock.wyborcza.pl/plock/7,35681,24687312,nie-slawa-grobupanskiego-w-plockim-kosciele-na-gorkach-bo.html (accessed on 17 December 2020).

Lipsky, Michael. 1980. Street Level Bureaucracy Dilemmas of the Individual in Public Services. New York: Russell Sage Foundation.

Ludwikowski, Rett R. 1991. Continuity and Change in Poland: Conservatism in Polish Political Thought. Washington, DC: Catholic University of America Press.

Lusch, Timothy D. 2017. A Demon Haunted Europe: Democracy's Totalitarian Impulse. New Oxford Review 84: 24-33.

Makarychev, Andrey. 2019. Multifaceted nationalism and illiberal momentum at Europe's eastern margins: An introduction to the special issue. European Politics $\mathcal{E}$ Society 20: 387-92. [CrossRef]

McManus, Matthew. 2020. The Rise of Post-Modern Conservatism. Neoliberalism, Post-Modern Culture, and Reactionary Politics. Cham: Palgrave Macmillan.

Mudde, Cas. 2007. Populist Radical Right Parties in Europe. Cambridge: Cambridge University Press.

Mudde, Cas. 2019. The Far Right Today. Cambridge: Polity.

Newsweek Polska. 2019. Awantury w płockim kościele. Wszystko przez słowa nienawiści o homoseksualistach. Available online: https: / / www.newsweek.pl/polska/awantury-w-plockim-kosciele-wszystko-przez-slowa-nienawisci-o-homoseksualistach/ 7tbbwj7 (accessed on 17 December 2020).

Nowak, Mattias. 2011. The Polish Christian Right and the idea of the West. In Cultural Transformations After Communism: Central and Eastern Europe in Focus. Edited by Barbara Törnquist-Plewa and Krzysztof Stala. Lund: Nordic Academic Press.

Nowak, Andrzej, and Marta Deszczyńska. 2018. Kościót na straży polskiej niepodległości. Kraków: Wydawnictwo Biały Kruk.

Onet.pl Wiadomości. 2019. Zatrzymanie Elżbiety Podleśnej. Politycy PiS komentują. Available online: https://wiadomosci.onet. $\mathrm{pl} / \mathrm{kraj} /$ sprawa-elzbiety-podlesnej-politycy-pis-komentuja-karczewski-kruk-brudzinski/5vbxq3n? (accessed on 17 December 2020).

Orłowski, Maciej. 2017. O. Rydzyk i papież Franciszek w tym samym czasie mówią o uchodźcach. Ale przekaz jest skrajnie różny.". Wyborcza.p. Available online: https:/ / wyborcza.pl/7,75398,22073492,o-tadeusz-rydzyk-straszy-uchodzcami-papiez-franciszekwzywa.html (accessed on 17 December 2020).

Ost, David. 1991. Shaping a New Politics in Poland: Interests and Politics in Post-Communist East Europe. Cambridge: Minda de Gunzburg Center for European Studies, Harvard University. 
Państwowa Komisja Wyborcza. 2019. Wyniki głosowania-Okręg wyborczy nr 13 [Gorzów Wielkopolski]. Available online: https: / / pe2019.pkw.gov.pl/pe2019/pl/wyniki/okr/13 (accessed on 25 November 2020).

Pew Research Center. 2018. The Age Gap in Religion around the World. Washington, DC: Pew Research Center.

Pietryga, Tomasz. 2019. Matka Boska w tęczowej aureoli: Terror podwójnych standardów. RP.pl. Available online: https://www.rp.pl/ Opinie/305079951-Matka-Boska-w-teczowej-aureoli-Terror-podwojnych-standardow.html (accessed on 17 December 2020).

Płonkowski, Tomasz. 2012. Multivocality of Cross in Polish Society Practices: The Symbolic Press Universe: The One or Many? An Analysis of Press Discourse Concerning "the Cross at the President's Palace" on an Example of Two Weeklies: "Gazeta Polska" and "Nie". Miscellanea Anthropologica et Sociologica 13. [CrossRef]

Polityka. 2016. Sejm odrzucił projekt wprowadzający całkowity zakaz aborcji. Kaczyński zdyscyplinował swoich posłów. Available online: https: / www.polityka.pl/tygodnikpolityka/kraj/1678348,1,sejm-odrzucil-projekt-wprowadzajacy-calkowity-zakazaborcji-kaczynski-zdyscyplinowal-swoich-poslow.read (accessed on 17 December 2020).

Porter-Szúcs, Brian. 2011. Faith and Fatherland: Catholicism, Modernity, and Poland. Oxford: Oxford University Press.

Presser, Stephen B. 2001. Law, Morality, and Religion. Chronicles-A magazine of American culture. Available online: https://www. chroniclesmagazine.org/law-morality-and-religion/ (accessed on 17 December 2020).

Radio Maryja. 2014. Pikiety pod tęczą na Placu Zbawiciela w Warszawie. Available online: https://www.radiomaryja.pl/informacje/ pikiety-pod-tecza-na-placu-zbawiciela-w-warszawie/ (accessed on 17 December 2020).

Ramet, Sabina. 2017. The Catholic Church in Polish History. From 966 to the Present. New York: Palgrave Macmillan.

Rohac, Dalibor, and Lance Kokonos. 2020. Poland's Culture Wars. Foreign Policy. Available online: https://foreignpolicy.com/2020/1 1/02/poland-hungary-culture-wars-abortion-russia/ (accessed on 17 December 2020).

Roszkowski, Wojciech. 2020. Bunt Barbarzyńców. 105 Pytań o Przyszłość Naszej Cywilizacji. Kraków: Wydawnictwo Biały Kruk.

RP.pl. 2019a. Matka Boska z tęczową aureola_-reakcja Helsińskiej Fundacji Praw Człowieka. Available online: https:/ /www.rp.pl/ Prawo-karne/305079970-Matka-Boska-z-teczowa-aureola---reakcja-Helsinskiej-Fundacji-Praw-Czlowieka.html?cid (accessed on 17 December 2020).

RP.pl. 2019b. Sellin o Podleśnej: Zawodowa prowokatorka. Available online: https://www.rp.pl/Rzad-PiS/190509443-Sellin-oPodlesnej-Zawodowa-prowokatorka.html (accessed on 17 December 2020).

RP.pl. 2019c. Karczewski: W Polsce inaczej się traktuje katolików. Available online: https:/ /www.rp.pl/Prawo-i-Sprawiedliwosc/19 0509524-Karczewski-W-Polsce-inaczej-sie-traktuje-katolikow.html (accessed on 17 December 2020).

RP.pl. 2020a. Tęczowa flaga na pomniku Chrystusa w Warszawie. Premier Morawiecki: Nie pozwolę! Available online: https://www. rp.pl/LGBT/200729495-Teczowa-flaga-na-pomniku-Chrystusa-w-Warszawie-Premier-Morawiecki-Nie-pozwole.html (accessed on 17 December 2020).

RP.pl. 2020b. Rafał Trzaskowski: Wieszanie jakiejkolwiek flagi na pomniku to niepotrzebna prowokacja. Available online: https: / www.rp.pl/Warszawa/200739895-Rafal-Trzaskowski-Wieszanie-jakiejkolwiek-flagi-na-pomniku-to-niepotrzebnaprowokacja.html?cid (accessed on 17 December 2020).

Ruksza, Stanisław. 2015. Julita Wójcik. Tęcza. Available online: https://sztukapubliczna.pl/pl/tecza-julita-wojcik/czytaj/122 (accessed on 17 December 2020).

Shields, Stuart. 2019. The paradoxes of necessity: Fail forwards neoliberalism, social reproduction, recombinant populism and Poland's 500Plus policy. Capital and Class 43: 653-69. [CrossRef]

Sofos, Spyros. 2019. Securitizing the "Other" in the European Far-Right Imaginary. Political Trends E Dynamics in Southeast Europe 2019: 23-26.

Sordyl, Grażyna. 1999. Spadkobiercy Stańczyków: Doktryna Konserwatyzmu Polskiego w Latach 1979-1989. Kraków: Wydawnictwo Dante.

Szczerski, Krzysztof. 2017. Utopia Europejska: Kryzys Integracji i Polska Inicjatywa Naprawy. Kraków: Biały Kruk.

Szeler, Jarosław. 2014. Tęcza Stop-Protest Przeciwko Powrotowi Instalacji na Plac Zbawiciela w Warszawie. wMeritum.pl. Available online: https: / wmeritum.pl/tecza-stop/39742 (accessed on 17 December 2020).

Szpała, Iwona. 2015. Wyborcza.pl Warszawa. Available online: https://warszawa.wyborcza.pl/warszawa/1,34862,18252008,Plac_ Zbawiciela_bez_Teczy_Plonela_szesc_razy_zniknie.html (accessed on 17 December 2020).

Szułdrzyński, Michał. 2019. Matka Boska w tęczowej aureoli: A jednak obraża ... . RP.pl. Available online: https://www.rp.pl/ Komentarze/190509578-Matka-Boska-w-teczowej-aureoli-A-jednak-obraza.html (accessed on 17 December 2020).

Tazbir, Janusz. 1973. A State without Stakes: Polish Religious Toleration in the Sixteenth and Seventeenth Centuries. The Library of Polish studies. New York: Kościuszko Foundation.

The Economist. 2013. Burning the Rainbow. Available online: https://www.economist.com/eastern-approaches/2013/11/18 /burning-the-rainbow (accessed on 17 December 2020).

Tocheva, Detelina. 2017. Intimate Divisions: Street-Level Orthodoxy in Post-Soviet Russia. Münster: Lit.

Törnquist-Plewa, Barbara. 1992. The Wheel of Polish Fortune: Myths in Polish Collective Consciousness during the First Years of Solidarity. Lund: Lund University.

TVP Info. 2019a. Profanacja Wizerunku Matki Boskiej w Płocku. Szef MSWiA: To Kulturowe Barbarzyństwo. Available online: https: / / www.tvp.info/42390029/profanacja-wizerunku-matki-boskiej-w-plocku-szef-mswia-to-kulturowe-barbarzynstwo (accessed on 17 December 2020).

TVP Info. 2019b. Ks. Bartołd: Jest Jakieś Przyzwolenie na Prześladowanie Chrześcijan. Available online: https:/ /www.tvp.info/4230 5616/ks-bartold-jest-jakies-przyzwolenie-na-przesladowanie-chrzescijan (accessed on 17 December 2020). 
Vignoles, Vivian L., Peter B. Smith, Maja Becker, and Matthew J. Easterbrook. 2018. In Search of a Pan-European Culture: European Values, Beliefs, and Models of Selfhood in Global Perspective. Journal of Cross-Cultural Psychology 49: 868-87. [CrossRef]

Walicki, Andrzej. 1982. Philosophy and Romantic Nationalism - The Case of Poland. Notre Dame: University of Notre Dame Press.

Wandowicz, Konrad. 2000. Wspótczesny Konserwatyzm Polityczny w Polsce (1989-1998). Wrocław: Wydawnictwo Uniwersytetu Wrocławskiego.

Weaver, Richard M. 1948. Ideas Have Consequences. Chicago: University of Chicago Press.

Więź. 2019. Katolicy przeciwko użyciu policji do ścigania Elżbiety Podleśnej. Available online: wiez.com.pl/2019/05/07/katolicyprzeciwko-uzyciu-policji-do-scigania-elzbiety-podlesnej/ (accessed on 17 December 2020).

Williamson, Chilton, Jr. 2001. What Is Paleoconservatism? Man, Know Thyself! Chronicles—A Magazine of American Culture. Available online: https:/ / www.chroniclesmagazine.org/what-is-paleoconservatism-2/ (accessed on 17 December 2020).

Wodak, Ruth. 2013. Right-Wing Populism in Europe: Politics and Discourse. London: Bloomsbury Publishing.

WP Wiadomości. 2010. Ziobro do Komorowskiego: Niech Pan tego nie robi. Available online: https:/ /wiadomosci.wp.pl/ziobro-dokomorowskiego-niech-pan-tego-nie-robi\$-\$6037715465065089a (accessed on 17 December 2020).

Wyborcza.pl. 2013a. Lider narodowców o tęczy: Spłonął symbol zarazy. Available online: https://wyborcza.pl/1,75248,14933380 ,Lider_narodowcow_o_teczy_splonal_symbol_zarazy.html\#TRrelSST (accessed on 17 December 2020).

Wyborcza.pl. 2013b. Odbudowa tęczy na placu Zbawiciela za 64 tys. złotych. Available online: https://warszawa.wyborcza.pl/ warszawa /1,54420,14724433,Odbudowa_teczy_na_placu_Zbawiciela_za_64_tys_zlotych.html?cta=1pbox\$-\$2cl\$-\$3noac\$-\$5 wydarzeniarok (accessed on 17 December 2020).

Wyborcza.pl Warszawa. 2014. Tęcza na pl. Zbawiciela znów została podpalona. Available online: https://warszawa.wyborcza.pl/ warszawa/1,34862,16440197,Tecza_na_pl_Zbawiciela_znow_zostala_podpalona.html\#LokWawTxt (accessed on 17 December 2020).

Yatsyk, Alexandra. 2019. Biopolitical conservatism in Europe and beyond: The cases of identity-making projects in Poland and Russia. Journal of Contemporary European Studies 27: 463-78. [CrossRef]

Zarycki, Tomasz, Rafał Smoczyński, and Tomasz Warczok. 2017. The roots of Polish culture-centered politics: Toward a non-purely cultural model of cultural domination in Central and Eastern Europe. East European Politics and Societies 31: 360-81. [CrossRef]

Żukiewicz, Przemysław, and Rafał Zimny. 2015. The Smolensk Tragedy and Its Importance for Political Communicationin Poland after 10th April, 2010 (Focusing on the Political Incidents in Front of the Presidential Palace). Środkowoeuropejskie Studia Polityczne 1: 63-82. [CrossRef] 